\title{
КОГНІТИВНО-КОМУНІКАТИВНІ ПАРАМЕТРИ АКТУАЛІЗАЦЇ̈ РОЛІ ДРУГ-ДОВІРЕНА ОСОБА В КОМУНІКАТИВНІЙ СИТУАЦІЇ “БЕСІДА ДРУЗІВ”
}

\section{Ірина Фролова, Росала Мусаєва}

\author{
Харківський наџіональний університет імені В. Н. Каразіна, \\ майдан Свободи, 4, м. Харків, Україна, 61022 \\ irinafrolova37@gmail.com rusalochka54@gmail.com
}

У статті проаналізовано актуалізацію ролі дРуг-дОВІРЕНА ОСОБА в комунікативній ситуації “БЕСІДА ДРУЗІВ”. На основі запровадження принципів когнітивно-комунікативного аналізу доведено, що саме роль суб'єкта виступає конституювальним чинником розглянутої комунікативної ситуації, іiі підтипів та різновидів. Зокрема, роль дРУГ-довІРенА осоБА, що актуалізується в процесі мовленнєвої взаємодії, утворює різновид “ДОВІРЕНА БЕСІДА ДРУЗІВ”. З’ясовано ментальне підгрунтя актуалізації ролі дРУг-довІРЕНА осоБА - стереотипні уявлення про друга, як особу, що варта довіри, та стереотип поведінки - сценарій, за яким це уявлення втілюється у комунікативну практику. Доведено, що провідною комунікативною характеристикою висловлень, побудованих на основі такого сценарію $€$ табуйована тема, яка пов'язана із повідомленням про невідповідність мовця певній нормі. Інші комунікативні характеристики є додатковими. Встановлено, що типовою є вербалізація ролі мовцем та іï приписування адресатові, котрий виступає як рольовий агент та може верифікувати свою відповідність ролі в експліцитній/імпліцитний спосіб.

Ключові слова: комунікативна ситуація, роль дРуг-довІРеНА ОСОБА, принципи когнітивно-комунікативного підходу, стереотипні уявлення, сценарій, тема, висловлення.

Вступ. У сучасну добу комунікативна ситуація $є$ поняттям, до якого прикута значна увага дослідників, адже “саме в останній період став очевидним факт існування типових комунікативних ситуацій, що дозволяє представити різновиди дискурсу та набори комунікативних ситуацій, які 3 ними співвіднесені, як комунікативний континіум" [3, с. 27].

Ця думка знаходить підтвердження в лінгвістичних студіях, де виявлено специфічні набори комунікативних ситуацій, властиві певному дискурсу [10; 22 та ін.], але розглянута в нашому дослідженні комунікативна ситуація “БЕСІДА ДРУЗІВ” є у цьому сенсі специфічною, адже лише вона репрезентує дискурс дружби [14].

Логічно припустити, що саме з цієї причини зазначена комунікативна ситуація диверсифікується на підтипи - кооперативний і некооперативний [15].

Учасники комунікативної ситуації “БЕСІДА ДРУЗІВ” вербалізують своє ставлення до іншого, спираючись на знання про “кодекс дружби” [21], якщо їхньою метою $\epsilon$ підтримування / укріплення дружніх взаємин (кооперативна “БЕСІДА ДРУЗІВ”). За наявності вагоміших, ніж збереження дружніх взаємин, причин, комуніканти можуть

(C) Фролова І., Мусаєва Р., 2019 
порушувати рольові приписи, це надає ситуації конфліктонебезпечного характеру та може призвести до сварки, а як наслідок - до припинення дружніх стосунків (некооперативна “БЕСІДА ДРУЗІВ”).

Кооперативний підтип комунікативної ситуації “БЕСІДА ДРУЗІВ” 3 усією очевидністю постає прототипним, демонструючи втілення основних соціопсихологічних чинників, притаманних справжній дружбі - близькості, взаєморозуміння, спільності поглядів, думок, довіри, підтримки тощо [21].

Вивчення дискурсу дружби та його репрезентеми - комунікативної ситуації “БЕСІДА ДРУЗІВ” - може бути продуктивним за умови, що пріоритет належить аналізу актуалізації ролі суб'єкта цієї ситуації, що й визначає фокус нашого дослідження.

3'ясування специфіки вербального втілення комунікативних ролей у різних ситуаціях і дискурсах належить до важливих і актуальних проблем сучасноїлінгвістики, оскільки виявляє зв'язки між мовою (вербальне втілення ролі), свідомістю (знання суб'єктів про стереотипи поведінки, пов'язані з рольовими правами та обов'язками) та комунікацією (досягнення мовленнєвих і немовленнєвих цілей в інтеракції шляхом актуалізації певної ролі).

Аналіз останніх досліджень і публікацій. Звертаючись до розгляду наявного досвіду вивчення проблематики роботи, варто погодитися 3 думкою, що “одним із складних і досі не вирішених питань у сучасній лінгвістиці $є$ проблема визначення й параметризації комунікативних ролей. Це питання $є$ проблемним 3 огляду на комплексний характер і багатоаспектність самого феномену комунікативної ролі, пов'язаного, у концептуальному аспекті, із мовною і комунікативною свідомістю рольових агентів і у комунікативному плані - із дискурсивною і інтерактивною природою ролі” [11, с. 88].

Справді, хоча вивченню комунікативних ролей приділено значну увагу в лінгвістичних студіях $[1$, с. $69 ; 6$, с. $64-65 ; 5$, с. $23 ; 8 ; 9 ; 12$, с. $78 ; 18$, с. 41-42; 20; 19 , с. 166 та ін.], відкритими залишаються ще чимало питань; зокрема, не є вичерпним дослідження взаємозв'язків між комунікативними ситуаціями та ролями їхніх учасників.

Науковці доводять, що певна комунікативна ситуація має специфічну рольову інфраструктуру [2, с. 64; 23 та ін.], але при цьому увага практично не зосереджується на тому, як актуалізована роль впливає на концептуалізацію комунікативної ситуації, iii типу/підтипу. Враховуючи специфіку досліджуваної комунікативної ситуації, вважаємо за необхідне зосередити увагу саме на цьому питанні.

У цьому розгляді спираємося на такі положення:

- природа ролей - сукупність прав, обов' язків та відповідних їм моделей поведінки - подана в специфічній національно-мовній свідомості у вигляді схематизованотипізованого усуспільненого - стереотипного - знання, вміст якого кореспондує 3 каноном (сукупністю поняттєвої інформації, типово асоційованої з певною роллю) та $з$ еталоном (ціннісною інформацією, репрезентованою оцінюванням поняттєвого змісту з опорою на лінгвокультурні нормативно-ціннісні орієнтири) [4, с. 8];

- поняттєвий зміст стереотипних ролей доцільно розглядати 3 опорою на соціологічний досвід як ієрархію або кластер, тобто систему, що охоплює базову роль і кластерні ролі $[4$, с. 9]. 
Викладене дає підстави сформулювати гіпотезу нашого дослідження, суть якої полягає у припущенні, що актуалізовані ролі виступають конституювальними чинниками кваліфікації комунікативної ситуації “БЕСІДА ДРУЗІВ”, іiі основних підтипів (кооперативного/ некооперативного) та подальшої диверсифікації у межах цих підтипів.

Очевидно, що базовою для досліджуваної комунікативної ситуації є роль ДРУГ, хоча досвід аналізу засвідчує, що навіть за умови іiі вербальної об'єктивації (my friend, my best friend тощо), ця роль не актуалізується як така, оскільки об' єктивується лише один з елементів ії поняттєвого змісту, а, отже, має місце вербалізація однієї 3 кластерних ролей.

Метою цієї розвідки є, зокрема, аналіз специфіки втілення (кластерної) ролі дРугДОВІРЕНА ОСОБА в комунікативній ситуації “БЕСІДА ДРУЗІВ” кооперативного типу.

Методологія дослідження. Дослідження проведено 3 опертям на методологію когнітивно-комунікативного аналізу [7], що збумовлює пріоритет когнітивних i комунікативних чинників і розгляд вербальних форм як засобів їхнього матеріального втілення.

Розглянемо детальніше ці принципи та відповідні процедури і методи аналізу.

Першим завданням стає виявлення структур свідомості, котрі лежать в основі ролей, як критерію їхньої параметризації. Це необхідно для виявлення суті та меж рольових приписів у якомога об'єктивніший спосіб.

Наприклад, у розвідці С. Г. Короткої, де вивчено прагматичну і концептуальну складові комунікативної ролі “ДОВІРЕНИЙ ДРУГ" у діалогах роману Беллоу "Герцог”, стверджується таке: "Когнітивним планом ролі є концепти спілкування, дружба, підтримка, участь, доцільність, спільні иінності, відданість, почуття обов'язку, а також пропозиції 'йому можна довіряти', 'на нього можна покластися', “їм можна користуватися', 'люди для нього найважливіше”' [11, с. 89].

Не вдаючись до дискусії стосовно “концептів” (у нашому розумінні - стереотипівуявлень, тобто декларативного знання) та “пропозицій” (у нашому трактуванні - стереотипів-поведінки або процедурального знання), зазначимо, що в розвідці відсутнє обгрунтування висловленої думки. Відтак, до переліку потрапляють одиниці, що вказують / не вказують на форму взаємодії (спілкування-відданість) і мають більш загальний/більш конкретний характер (дружба-підтримка) тощо.

Аби уникнути таких неточностей, використовуємо методи когнітивносемантичного аналізу, а саме: метод аналізу словникових дефініцій та метод когнітивного моделювання.

Дефініції номінативних одиниць, де останні постають як імена концептів, використовують як основу для побудови лексико-семантичного поля - репрезентанта концептуалізованого знання (див., наприклад, [17]). Але ми враховуємо той факт, що, аналізуючи роль, ми маємо справу зі стереотипним знанням, яке відрізняється “від лінгвокультурного концепту спрощеністю та узагальненістю” [4, с. 8]. Виходячи 3 цього, зі словникових дефініцій виокремлюємо лише основні, типові складники, на основі яких моделюємо стереотипні уявлення.

У словнику Merriam Webster, приміром, міститься така дефініція: trustworthiness 
- something committed or entrusted to one to be used or cared for in the interest of another [24, с. 1269] (подібними є й інші дефініції в англомовних тлумачних словниках). Звідси випливає, що поняттєвими складниками довіри є можливість поділитися 3 іншим інформацією, впевненість у тому, що інший буде діяти в твоїх інтересах.

Це декларативне знання в комунікації втілюється у вигляді когнітивних сценаріїв, які розробляємо за методикою, запропонованою у [23] (від сценаріїв А. Вежбицької вони відрізняються необмеженістю мовного наповнення). Отже, основою ролі дРугдовІРЕНА оСоБА вважаємо сценарій:

Я тут зараз кажу тобі щзось, щзоб ти знав ц̧е,

Я не можу сказати це іншим,

Я вірю, щуо знаючи цее, ти будеш діяти на мою користь.

Другим завданням постає аналіз комунікативних особливостей втілення ролей.

Під час його виконання поділяємо думку про те, що комунікативні характеристики мають три іпостасі: прагмасемантичну/актомовленнєву, змістову (тематичну), структурно-інтеракційну (позиція в діалозі), де перші дві виступають як основні, а третя - як додаткова [23].

У практичному сенсі це здійснюється у такий спосіб:

- висловлення, підгрунтям якого є відповідний сценарій, досліджують під кутом зору того, яка його властивість найбільше втілює цей сценарій (у попередньому дослідженні ми, приміром, з'ясували, що для актуалізації кластерної ролі другПРИємний спІвРОзмовник це - актомовленнєва характеристика, зокрема мовленнєвий акт - фатичний метакомунікатив) [16]);

- виявлену характеристику висловлення аналізують з опорою на відповідні теоретичні положення і методи (прагмасемантичний або актомовленнєвий аналіз, інтерпретація тексту);

- описують інші характеристики висловлення у разі їхньої релевантності, зокрема за потреби долучається метод конверсаційного аналізу.

До методологічно важливих настанов нашого дослідження також належить ідея про те, що художні твори виступають як модель реальних комунікацій, яка достатньо достовірна для мовознавчого аналізу [25 та ін.], оскільки доведено, що в основі реального та художнього діалогу лежить спільний досвід людського спілкування [13, c. 35].

Виходячи 3 цього, ми використали в якості матеріалу дослідження художній діалог (діалогову взаємодію персонажів), що відповідає традиції комунікативно зорієнтованих студій. Послуговуючись можливостями, що сьогодні відкривають інформаційні технології, ми зосередилися не на літературних творах, а на творах ігрового кіно, що наявні в мережі Інтернет як у вигляді фільмів чи телесеріалів, так і у текстовій репрезентації (скрипти).

Для більшої достовірності використаного матеріалу ми дотримувалися низки таких умов як сучасність, популярність (в англомовному світі), жанрова і тематична різноманітність.

Результати дослідження та їхне обгрунтування. Аналіз фактичного матеріалу засвідчив, що в актуалізації (кластерної) ролі дРуг-довІРЕНА осоБА провідною 
комунікативною характеристикою виступає тема, тоді як актомовленнєва або прагмасемантичні та інтеракційні властивості висловлень є додатковими.

Усі теми в діалогах, де вербалізується вказана роль, можна визначити як табуйовані: їхне обговорення можливо тільки в колі близьких людей, воно не призначене для широкого загалу.

Вербальними знаками, котрі виступають смисловими опорами референції та вказують на тему, є лексичні одиниці, словосполучення, мовні вирази та цілі висловлення, які підкреслені у поданих далі прикладах.

У фрагменті (1) хлопець зізнається другові, що вкрав гроші, а, отже, порушив правову та етичну норми:

(1) - Something I've been meaning to tell you, something, I didn't want to say in front of Sue.

- Yeah, what's that?

- I didn't save up that money.

- Where did you get it?

- I stole it from Giff.

- You... what?

- Yeah, walked right into his office. Took it from his safe.

- Fuck you, that's bullshit.

- Swear it.

-OK, so what the fuck's that have to do with you breaking into his safe?

- Well, I figured it out. It's his pin number.

- It's gotta be the dumbest thing I ever heard.

- Yeah, kind of serves him right.

- Can't believe you stole that money.

- Just don't say anybody, all right?

- I won't (Bad Turn Worse).

У цій розмові Бі Джей розповідає Боббі про вкрадені гроші й тим самим об'єктивує роль дРУг-ДОВІРЕНА осОБА, підсилюючи реалізацію цієї ролі посиланням на те, що може поділитися інформацією тільки з Боббі (I didn't want to say in front of Sue), розкриттям усіх деталей скоєного ним злочину (... walked right into his office. Took it from his safe, ... figured it out. It's his pin number) та проханням нікому нічого не розповідати (Just don't say anybody, all right?). Отже, Бі Джей демонструє повну довіру до свого друга, котрий у цій ситуації “БЕСІДА ДРУЗІВ” виступає як рольовий агент, тобто носій ролі ДРУГ-ДОВІРЕНА ОСОБА.

Висловлення, що представляють (мікро)тему “крадіжка грошей” функціонують як мовленнєві акти - репрезентативи прагмасемантичного типу повідомлення. У той самий час, усі висловлення, продуковані мовцем-об'єктиватором ролі, містяться в ініціальних репліках.

Рольовий агент - Боббі - у перебігу діалогу майже не вдається до рольової поведінки: він висловлює здивування, питає про деталі і лише в останній респонсивній репліці реалізує мовленнєвий акт - комісив промисивного прагмасемантичного типу, верифікуючи приписувану йому роль. Іншими словами, якщо Бі Джей об'єктивує 
когнітивний сценарій, що лежить у підгрунті ролі дРуг-дОВІРЕНА ОСОБА, то в основі реакції Боббі лежить когнітивна модель верифікацій (це так $i \epsilon$ ).

Приклад (2) є дещо подібним до попереднього: у ньому жінка також зізнається подрузі в тому, що ऑiі чоловік вбив іiі вітчима, намагаючись захистити іiі. Таким чином, Габбі порушила правову норму (не повідомила поліцію про скоєний злочин) і етичну норму (на іiї думку, саме вона винна у вбивстві, через що ії чоловіка можуть ув'язнити):

(2) - Gaby? What happened?

- I killed him.

- And now he's gonna go to jail because he was trying to protect me.

- Calm down. We just need time to think (Desperate Housewives).

Як і в попередньому випадку, мовець (Габбі) вербалізує роль ДРуг-довІРЕнА осоБА, повідомляючи подрузі інформацію, яка компроментує іiі саму та іiі чоловіка, а, отже, визначає адресата (Сьюзен) як рольового агента, тобто носія цієї ролі. Висловлення Габбі функціонують також як мовленнєві акти - репрезентативи прагмасемантичного різновиду повідомлення. Єдина відмінність полягає у тому, що висловлення Габбі містяться у респонсивній репліці, вони є відповіддю на запитання подруги.

Своєю чергою, Сьюзен, як рольовий агент, у цьому фрагменті не вдається до експліцитної верифікації ролі, хоча її реакція на повідомлення Габбі можна розглядати як імпліцитну рольову верифікацію (якщо Сьюзен намагається заспокоїти подругу, очевидно, що вона має намір діяти на ії користь).

У фрагменті (3) Одрі, хоча й не без вагань, довіряє своїй подрузі надзвичайно небезпечну інформацію: хлопець, із яким вона зустрічалася, несподівано виявився секретним агентом, і тепер вона має за його дорученням перевезти за кордон флешку, на яку полюють злочинці. Після того, як іiі обдурив та ще й кинув хлопець, Одрі має сумніви у тому, чи можна взагалі комусь довіряти, але зрештою вирішує відкритися подрузі.

(3) - Sorry, can I ask a question?

- Who is this?

- That's the asshole from the CIA.

- Audrey, where are you taking it?

- Why would I tell you?

- Trust me.

- I don't trust anyone anymore.

- You trust me though, right?

- Yes, of course, I trust you. You don't count.

- Good. 'Cause this is not some fake spy friendship that the Russians put together.

- Dude, shut up. I know.

- Okay, Drew said that if we don't deliver this package, a lot of people are gonna die.

- What if we don't do it and then there's a terrorist attack or something?

- Well, what did he say to do?

- We have to get it to a cafe in Vienna.

- Austria, Vienna? 
- Yes. That's what he said (The Spy who dumped me).

У поданому діалозі роль дРуГ-довІРенА осоБА об'єктивується по-перше, за рахунок номінації trust, по-друге, через підкреслені у тексті смислові опори, які кореспондують із (мікро)темою “небезпечні обставини". Таким чином, якщо в попередніх фрагментах елемент ЩОСЬ у сценарії (Я тут зараз кажу тобі ЩОСь...) кореспондує з негативною оцінкою, закоріненою у невідповідності дій мовця певним нормам, то у діалозі (3) негативна оцінка кореспондує зі змістом повідомлюваного - описом обставин, що несуть у собі загрозу для комунікантів, тобто йдеться про невідповідність екзистенційній нормі.

Повідомляючи Морган таку небезпечну інформацію, Одрі тим самим об’єктивує iii роль ДРУГ-ДОВІРенА ОСОБА. У той самий час, на початку розмови сама Морган рольовий агент - спонукає подругу до вербалізації ролі (Trust me. You trust me through, right?).

Висловлення Одрі, де об’єктивована роль дРУГ-дОВІРЕНА ОСОБА, функціонують, як і в попередніх фрагментах, як мовленнєві акти - репрезентативи прагмасемантичного типу повідомлення. У цьому діалозі усі висловлення Одрі, що вербалізують зазначену роль, розташовані у респонсивних репліках обмінів типу питання-відповідь (Морган ставить запитання, Одрі надає відповідь).

У наступному фрагменті комунікант довіряє другові таємницю, з якою не хоче ділитися з іншими: він носить взуття на підборах, щоб приховати свій малий зріст:

(4) - Great to--great to meet you.

- Yeah.

- Well, then take the shoes off.

- No, no.

- I'm-I'm such a shorty.

- Who cares?

- I don't want your friends to know how short I am.

- Ha-ha!

- It's a secret.

- It's a secret? All right, I won't tell anyone (Drinking Buddies).

У цьому діалозі мовець, як в попередніх випадках, вербалізує роль дРугДОВІРЕНА ОСОБА, приписуючи цю роль адресатові, котрий виступає рольовим агентом. Повідомлювана інформація, з погляду мовця, $є$ негативно забарвленою для нього (ЩОСЬ $є$ ПОГАНЕ), оскільки кореспондує з порушенням естетичної норми. Актуалізація ролі, здійснювана за рахунок мовленнєвих актів - репрезентативіє прагмасемантичного підтипу повідомлення міститься тут в ініціальних ходах та підсилюється експліцитною кваліфікацією повідомлюваної інформації як секретної, тобто такої, котру мовець може довірити лише другові (It’s a secret).

Рольовий агент експліцитно верифікує свою роль, реалізуючи мовленнєвий акт - комісив промисивного прагмасемантичного підтипу: він обіцяє зберегти таємницю друга, діючи, таким чином, на його користь.

У фрагменті (5) йдеться про те, що хтось зателефонував із дому Емілі, і це спричинило надзвичайно тяжкі наслідки - сталося вбивство. Майк - поліцейський $\mathrm{i}$ 
друг Емілі - хоче дізнатися, що трапилося. Емілі, яка не телефонувала нікому в той вечір, запевняє Майка, що каже правду:

(5) - You wanted to talk about something?

- There was a call that night before the murder.

- From who?

- The call came from your house, Emily.

- What?

- I'm not accusing you of anything, I just want to know what was said.

- But that's impossible.

- I'm talking to you as a friend, you know that, right?

- Mike, did you not hear me? As a friend, I'm telling you that I didn't call that family (Case № 39).

У цьому прикладі роль дРуг-довІРЕНА осоБА об'єктивують обидва комуніканта: Майк каже, що розмовляє з Емілі не як поліцейський, а як іiі друг (I'm talking to you as a friend, you know that, right?), а Емілі відповідає, що й вона спілкується з Майклом як із другом (As a friend, I'm telling you that I didn't call that family).

Специфіка цього діалогу полягає у тому, що тут провідною характеристикою висловлень, що вербалізують роль друг-довІРЕнА осоБА $є$ не власне (мікро)тема телефонна розмова, а тематичний модус, а саме модус протиставлення у рамках верифікативної модальності (істинно/неістинно). Зокрема, стверджуючи, що хтось розмовляв по телефону з дому Емілі (There was a call that night before the murder), Майкл додає, що говорить з Емілі як друг. У цих обставинах він має на увазі, що довіряє Емілі, вірить, що вона не діятиме йому на шкоду, а, отже, скаже правду. Емілі, заперечуючи факт телефонної розмови, теж підкреслює, що діє як друг, особа, що варта довіри. Таким чином, у цьому контексті мовний вираз as a friend виступає як генералізувальний об'єктиватор ролі, і саме контекстні чинники дозволяють конкретизувати цю роль.

Висновки. Отже, роль виступає конституювальним чинником комунікативної ситуації “БЕСІДА ДРУЗІВ”, оскільки реалізація ролі ДРУГ-ДОВІРЕНА осОБА формує у межах цієї ситуації кооперативного підтипу такий різновид, як “ДОВІРЛИВА БЕСІДА ДРУЗІВ”.

Можна також зробити низку конкретніших висновків. По-перше, можна стверджувати, що ментальною основою вербального втілення (кластерної) ролі другдовІРЕНА осОБА виступають (1) стереотипні уявлення про можливість поділитися 3 кимось специфічною інформацією та впевненість у тому, що ця людина діятиме на користь мовця; (2) стереотипна модель комунікативної поведінки - сценарій, за допомогою якого стереотипні уявлення втілюються в процес мовленнєвої взаємодії. По-друге, як засвідчило дослідження, висловлення, побудовані на основі такого сценарію, мають специфічну (табуйовану) тему, оскільки повідомлювана інформація кореспондує з порушенням норм - екзистенційної (небезпечно), правової (незаконно), етичної (неетично), естетичної (неестетично). Крім того, тематизовані висловлення містять вербальні одиниці, котрі виступають як смислові опори у вибудуванні ланцюжку мовні одиниці - референція висловлення - мікротема. Додатковими 
характеристиками цих тематизованих висловлень $є$ їхнє функціонування як мовленнєвих актів - репрезентативів прагмасемантичного підтипу повідомлення у складі ініціальної/респонсивної репліки діалогу. I, нарешті, можна стверджувати, що роль ДРУГ-ДОВІРЕНА оСОБА головно вербалізується за умов, що мовець приписує iii адресатові, а той, виступаючи рольовим агентом, може експліцитно/імпліцитно верифікувати свою відповідність цій ролі. У випадку, коли комуніканти поєднують ролі ДРУГ і ПАРТНЕР, вербальна експлікації ролі дРУГ-дОВІРЕНА ОсоБА здійснюється за рахунок мовних засобів генералізованого змісту, котрі зазнають конкретизації у певних обставинах взаємодії.

Перспективою роботи $є$ виявлення специфіки актуалізації ролі суб'єкта в комунікативній ситуації “БЕСІДА ДРУЗІВ” некооперативного підтипу.

\section{СПИСОК ВИКОРИСТАНОЇ ЛІТЕРАТУРИ}

1. Аврорин В. А. Проблемы изучения функциональной стороны языка (к вопросу о предмете социолингвистики) / В. А. Аврорин. - Л. : Наука, 1975. - 276 с.

2. Белова А. Д. Лингвистические аспекты аргументации : монография / А. Д. Белова. Киев : Киев. ун-т им. Тараса Шевченко, ИИА “Астрея”, 1997. - 310 с.

3. Бєлова А. Д. Лінгвістичні перспективи і прогнози у ХХІ столітті / А. Д. Бєлова // Лінгвістика XXI століття: нові дослідження і перспективи. - Київ : Логос, 2006. № 1. С. 22-31.

4. Гридасова О. І. Особливості актуалізації стереотипних ролей в англомовному сімейному конфліктному дискурсі: автореф. дис. на здобуття наук. ступеня канд. філол. наук : спец. 10.02.04 "Германські мови" / Гридасова О. І. - Харків, 2010. - 20 с.

5. Дейк ван Т. А. Язык. Познание. Коммуникация / Т. А. ван Дейк ; [пер. с англ. ; сост. Петров В. В. ; под ред. Гарасимова]. - М. : Прогресс, 1989. - 310 с.

6. Смельянова О. В. Мовленнєве вираження статусу адресата в англомовному художньому дискурсі закоханих : дис. ... канд. філол. наук : 10.02 .04 / Смельянова Олена Валеріанівна. - Суми, 2006. - 219 с.

7. Как нарисовать портрет птицы: методология когнитивно-коммуникативного анализа языка : кол. монография / Е. В. Бондаренко, А. П. Мартынюк, И. Е. Фролова, И. С. Шевченко ; под. ред. И. С. Шевченко. - Харьков : ХНУ имени В. Н. Каразина, 2017. $-246 \mathrm{c}$.

8. Карасик В. И. Языковой круг: личность, концепты, дискурс / В. И. Карасик. Волгоград : Перемена, 2002. - 447 с.

9. Карасик В. И. Язык социального статуса / В. И. Карасик. - Москва : ИТДГК “Гнозис", 2002. $-333 \mathrm{c}$.

10. Кобзєва О. О. Стратегії та тактики судді в американському судовому дискурсі: автореф. дис. на здобуття наук. ступеня канд. філол. наук: спец. 10.02.04 "Германські мови" / Кобзєва О. О. - Харків, 2017. - 20 с.

11. Коротка С. Г. Прагматична і концептуальна складові комунікативної ролі “довірений друг” в діалогах роману Сола Беллоу “Герзог” / С. Г. Коротка // Вісник Харківського національного університету імені В. Н. Каразіна. - 2013. - № 1051. - С. 88-92.

12. Крысин Л. П. Социальный компонент в семантике языковых единиц / Л. П. Крысин // Русский язык в школе. - 1983. - № 3. - С. 78-84.

13. Лагутин В. И. Проблемы анализа художественного диалога (к прагмалингвистической теории драмы) / В. И. Лагутин. - Кишинев : Штиинца, 1991. - 98 с. 
14. Мусаєва Р. Ш. Дискурсивні властивості комунікативної ситуації “Дружня Бесіда” / Р. Ш. Мусаєва // Вісник Харківського національного університету імені В.Н. Каразіна. - Харків : Константа, 2014. - № 1124. - С. 137-143.

15. Мусаєва Р. Різновиди комунікативної ситуації “Бесіда друзів” / Р. Мусаєва // Сучасна англістика: до 85-річчя кафедри англійської філології: Шостий міжнародний науковий форум, 23.09.2015 р. - Харків : ХНУ імені В.Н. Каразіна, 2015. - С. 89-91.

16. Мусаєва Р. Ш. Особливості актуалізації ролі Друг-Приємний співрозмовник у ситуації “Бесіда Друзів" / Р. Ш. Мусаєва // Вісник Харківського національного університету імені В. Н. Каразіна. - Харків : Константа, 2015. - Вип. 81. - С. 119-125.

17. Петренко О. М. Стратегії неввічливості у дискурсі драм В. Шекспіра: когнітивно-прагматичний аспект: автореф. дис. на здобуття наук. ступеня канд. філол. наук: спец. 10.02.04 "Германські мови" / Петренко О. М. - Харків, 2018. - 20 с.

18. Почепцов О. Г. Комунікативний статус як параметр мовленнєвої взаємодії / О. Г. Почепцов // Мовознавство. - 1989. - № 4. - С. 40-45.

19. Селиванова Е. А. Основы лингвистической теории текста и коммуникации / Е. А. Селиванова. - К. : ЦУА “Фитосоциоцентр”, 2002. - 336 с.

20. Скриннік Ю. С. Дискурсивна варіативність вербальної та невербальної поведінки мовців при зміні соціальних ролей (на матеріалі англійської мови): автореф. дис. на здобуття наук. ступеня канд. філол. наук: спец. 10.02.04 "Германські мови" / Скриннік Ю. С. - Харків, 2019. - 20 с.

21. Справжня дружба [Електронний ресурс]. - Режим доступу до ресурсу: http://www. ukrlit.vn.ua/makingl/6pvlf.html.

22. Фещенко О. В. Інституційність дискурсу американського слідства: автореф. дис. на здобуття наук. ступеня канд. філол. наук: спец. 10.02.04 "Германські мови” / Фещенко О. В. - Харків, 2017. - 20 с.

23. Фролова I. С. Регулятивний потенціал стратегії конфронтації в англомовному дискурсі: дис. ... доктора філол. наук : 10.02.04 / Фролова Ірина Євгенівна. - Харків, 2015. $-508 \mathrm{c}$.

24. Merriam Webster's Collegiate Dictionary. - [tenth edition]. - Springfield, Mass., 1993. $1559 \mathrm{p}$.

25. Tannen D. Gender and Discourse / D. Tannen. - New York, Oxford : OUP, 1994. - 203 p.

\section{REFERENCES}

1. Avrorin V. A. Problemy izuchenija funkcional'noj storony jazyka (k voprosu o predmete sociolingvistiki) [The problems of studying the functional aspect of language (the problem of sociolinguistics object)] / V. A. Avrorin. - L .: Nauka, 1975. - 276 s.

2. Belova A. D. Lingvisticheskie aspekty argumentacii [Linguistic aspects of argumentation]: monografija / A. D. Belova. - Kiev: Kiev. un-t im. Tarasa Shevchenko, IIA “Astreja”, 1997. $-310 \mathrm{~s}$.

3. Bielova A. D. Linhvistychni perspektyvy i prohnozy u KhKhI stolitti [Linguistic perspectives and forecasts in the XXI century] / A. D. Bielova // Linhvistyka KhKhI stolittia: novi doslidzhennia i perspektyvy. - Kyiv : Lohos, 2006. - № 1. - S. 22-31.

4. Hrydasova O. I. Osoblyvosti aktualizatsii stereotypnykh rolei v anhlomovnomu simeinomu konfliktnomu dyskursi [Characteristic Features of Stereotypical Roles Actualization in the English Speaking Family Conflict Discourse]: avtoref. dys. na zdobuttia nauk. stupenia kand. filol. nauk : spets. 10.02.04 "Hermanski movy" / Hrydasova O. I. - Kharkiv, 2010. $20 \mathrm{~s}$. 
5. Dejk van T. A. Jazyk. Poznanie. Kommunikacija [Language. Cognition. Communication] / T. A. van Dejk ; [per. s angl. ; cost. Petrov V. V. ; pod red. Garasimova]. - M. : Progress, 1989. $-310 \mathrm{c}$.

6. Iemelianova O. V. Movlennieve vyrazhennia statusu adresata v anhlomovnomu khudozhnomu dyskursi zakokhanykh [Speech Realization of Addressee's Status in the English Lovers' Discourse of Fiction]: dys. ... kand. filol. nauk : 10.02.04 / Yemelianova Olena Valerianivna. - Sumy, 2006. - 219 s.

7. Kak narisovat' portret pticy: metodologija kognitivno-kommunikativnogo analiza jazyka [How do Draw the Portrait of a Bird]: kol. monografija / E. V. Bondarenko, A. P. Martynjuk, I. E. Frolova, I. S. Shevchenko ; pod. red. I. S. Shevchenko. - Har'kov : HNU imeni V. N. Karazina, 2017. -246 s.

8. Karasik V. I. Jazykovoj krug: lichnost', koncepty, diskurs [Language circle: Identity, Concepts, Discourse] / V. I. Karasik. - Volgograd : Peremena, 2002. - 447 s.

9. Karasik V. I. Jazyk social'nogo statusa [The Language of the Social Status] / V. I. Karasik. - Moskva : ITDGK “Gnozis”, 2002. - 333 s.

10. Kobzieva O. O. Stratehii ta taktyky suddi v amerykanskomu sudovomu dyskursi [Judge's Strategies and Tactics in American Courtroom Discourse]: avtoref. dys. na zdobuttia nauk. stupenia kand. filol. nauk: spets. 10.02.04 "Hermanski movy" / O. O. Kobzieva. - Kharkiv, 2017. $-20 \mathrm{~s}$.

11. Korotka S. H. Prahmatychna i kontseptualna skladovi komunikatyvnoi roli "dovirenyi druh" v dialohakh romanu Sola Bellou "Herzoh" [Pragmatic and conceptual components of the communicative role "trusted friend" in dialogues of the novel of Saul Bellow "Herzog"] / S. H. Korotka // Visnyk Kharkivskoho natsionalnoho universytetu imeni V.N. Karazina. 2013. - № 1051. - S. 88-92.

12. Krysin L. P. Social'nyj komponent v semantike jazykovyh edinic [The Social Component in the Semantics of Language Units] / L. P. Krysin // Russkij jazyk v shkole. - 1983. - № 3. - S. 78-84.

13. Lagutin V. I. Problemy analiza hudozhestvennogo dialoga (k pragmalingvisticheskoj teorii dramy) [The Problems of Literary dialogue Analysis (the pragmalinguistics theory of drama)] / V. I. Lagutin. - Kishinev : Shtiinca, 1991. - 98 s.

14. Musaieva R. Sh. Dyskursyvni vlastyvosti komunikatyvnoi sytuatsii "Druzhnia Besida" [Communicative Situation "Friendly Talk" Discoursive Properties] / R. Sh. Musaieva // Visnyk Kharkivskoho natsionalnoho universytetu imeni V. N. Karazina. - Kharkiv : Konstanta, 2014. - № 1124. - C. 137-143.

15. Musaieva R. Riznovydy komunikatyvnoi sytuatsii "Besida druziv" [Subtypes of the communicative situation "Talk of Friends"] / R. Musaieva // Suchasna anhlistyka: do 85-richchia kafedry anhliiskoi filolohii: Shostyi mizhnarodnyi naukovyi forum, 23.09.2015 r. - Kharkiv : KhNU imeni V. N. Karazina, 2015. - C. 89-91.

16. Musaieva R. Sh. Osoblyvosti aktualizatsii roli Druh-Pryiemnyi spivrozmovnyk u sytuatsii "Besida Druziv" [The peculiarities of actualization of the role FRIEND-GOOD COMPANY in the situation "Talk of Friends"] / R. Sh. Musaieva // Visnyk Kharkivskoho natsionalnoho universytetu imeni V.N. Karazina. - Kharkiv : Konstanta, 2015. - Vyp. 81. - C. 119-125.

17. Petrenko O. M. Stratehii nevvichlyvosti u dyskursi dram V. Shekspira: kohnityvnoprahmatychnyi aspect [Impoliteness strategies in the discourse of Shakespearean dramas: a cognitive-pragmatic aspect]: avtoref. dys. na zdobuttia nauk. stupenia kand. filol. nauk: spets. 10.02.04 "Hermanski movy" / Petrenko O. M. - Kharkiv, 2018. - 20 s.

18. Pocheptsov O. H. Komunikatyvnyi status yak parametr movlennievoi vzaiemodii [Communicative status as speech interaction parameter] / O. H. Pocheptsov // Movoznavstvo. - 1989. - № 4. - S. 40-45. 
19. Selivanova E. A. Osnovy lingvisticheskoj teorii teksta i kommunikacii [The Foundations of the Linguistics Theory of Text and Communication] / E. A. Selivanova. - K. : CUA "Fitosociocentr", 2002. - $336 \mathrm{~s}$.

20. Skrynnik Yu. S. Dyskursyvna variatyvnist verbalnoi ta neverbalnoi povedinky movtsiv pry zmini sotsialnykh rolei (na materiali anhliiskoi movy) [Discursive variativity of the speaker's verbal and non-verbal behavior in the process of changing social roles (based on the English language material)]: avtoref. dys. na zdobuttia nauk. stupenia kand. filol. nauk: spets. 10.02.04 "Hermanski movy" / Skrynnik Yu. S. - Kharkiv, 2019. - 20 s.

21. Spravzhnia druzhba [True Friendship] [Elektronnyi resurs]. - Rezhym dostupu do resursu : http://www.ukrlit.vn.ua/makingl/6pvlf.html.

22. Feshchenko O. V. Instytutsiinist dyskursu amerykanskoho slidstva [Institutional Characteristics of American Criminal Investigation Discourse]: avtoref. dys. na zdobuttia nauk. stupenia kand. filol. nauk: spets. 10.02.04 "Hermanski movy" / Feshchenko O. V. Kharkiv, 2017. $-20 \mathrm{~s}$.

23. Frolova I. Ye. Rehuliatyvnyi potentsial stratehii konfrontatsii v anhlomovnomu dyskursi [Regulatory Potential of Confrontation Strategy in English-Language Discourse]: dys. ... doktora filol. nauk : 10.02.04 / Frolova Iryna Yevhenivna. - Kharkiv, 2015. - 508 c.

24. Merriam Webster's Collegiate Dictionary. - [tenth edition]. - Springfield, Mass., 1993. $1559 \mathrm{p}$.

25. Tannen D. Gender and Discourse / D. Tannen. - New York, Oxford : OUP, 1994. - 203 p.

\title{
COGNITIVE-COMMUNICATIVE PARAMETERS OF ACTUALIZING \\ THE ROLE FRIEND-A TRUSTWORTHY PERSON \\ IN THE COMMUNICATIVE SITUATION "TALK OF FRIENDS"
}

\section{Iryna Frolova, Rosala Musaieva}

\author{
V. N. Karazin Kharkiv National University, \\ 4, Svobody Sq., Kharkiv, Ukraine, 61022 \\ irinafrolova37@gmail.com,rusalochka54@gmail.com
}

\begin{abstract}
This article focuses on the study of the communicative role FRIEND-A TRUSTWORTHY PERSON in view of its influence on the situation "TALK OF FRIENDS" of a cooperative type.

The communicative situation "TALK OF FRIENDS" is the only one to represent the discourse of friendship. The communicative roles, realized by the interlocutors in this situation, serve to distinguish it from the others as well as to define the subtypes of the situation - cooperative and non-cooperative ones. Each of the subtypes can further be subdivided into a number of varieties depending upon the realized roles.

Communicative roles in linguistic studies are approached as models of declarative stereotyping knowledge (stereotypes-images) and procedural stereotypical knowledge (behavioral stereotypes), implemented through the use of linguistic signs. In terms of sociological and linguistics analyses,
\end{abstract}


communicative roles are described as clusters (a hierarchy) comprising a basic role and a number of cluster roles.

This study is underpinned with the principles of cognitive-communicative methodological approach which predetermines the procedures and methods of our research. The first stage of the analysis is aimed at establishing the stereotypical image - declarative knowledge underlying the role realization through the study of the most typical semantic components of its name. This provides grounds to work out a scenario for this role, the model of procedural stereotypical knowledge. The second stage aims at the study of the communicative features of the utterances formed on the basis of the scenario, one of these features (speech act/pragmasemantical, content/thematic, conversational) being the main one.

The analysis of the role FRIEND-A TRUSTWORTHY PERSON gives grounds to argue that it serves to form epy "TRUSTFUL TALK of FRIENDS" variety within the cooperative subtype of the communicative situation "TALK of FRIEND".

The study also allows to basically state, as a conclusion, the following:

- the realization of the role FRIEND-A TRUSTWORTHY PERSON rests on the stereotypical image, specialized in the scenario - the behavioral model of telling somebody something which cannot be shared with others;

- the main communicative feature of the utterances that embody this role is its topic that is a taboo for all but the addressee because the information shared violates certain norms;

- the role agent is, as a rule, the addressee, while the person who realizes the role is the speaker.

Key words: communicative situation, role FRIEND-A TRUSTWORTHY PERSON, principles of cognitivecommunicative analysis, stereotypical images, scenario, topic, utterance. 